\title{
Analisis Pengaruh Belanja Daerah Dana Perimbangan dan Pendapatan Asli Daerah Terhadap Produk Domestik Bruto di Provinsi Aceh Periode 2013-2017
}

Cut Putri Mellita Sari ${ }^{* a}$

* Fakultas Ekonomi dan Bisnis Universitas Malikussaleh

a Corresponding author:cmellita0674@gmail.com

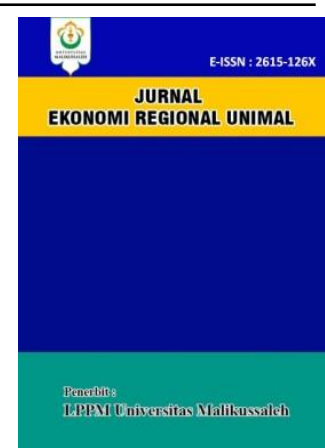

A RT I CLE INFORMATION

A B S T R A C T

Keywords:

Regional Expenditures, Balancing Funds, PAD, GRDP

This study aims to analyze the Effect of Regional Expenditures, Balancing Funds and Regional Original Income on Gross Domestic Product in Aceh Province for the 2013-2017 Period. The data used in this research is secondary data. The method used in this study is using multiple regression analysis. The results show that Regional Expenditures has a positive and significant influence on GDP. While the Balancing Funds and Regional Original Income (PAD) negatively and significantly affect GDP.

\section{PENDAHULUAN}

Produk Domestik Regional Bruto (PDRB) merupakan indikator yang baik dalam menganalisis kondisi perekonomian suatu wilayah.Salah satu tujuan yang pasti dari proses pembangunan nasional adalah pertumbuhan ekonomi tinggi dan merata, baik dalam jangka pendek maupun jangka panjang. Provinsi Aceh merupakan salah satu provinsi yang memiliki PDRB yang baik dalam kurun waktu 2013-2017. Kondisi tersebut dapat dilihat pada gambar di bawah ini :

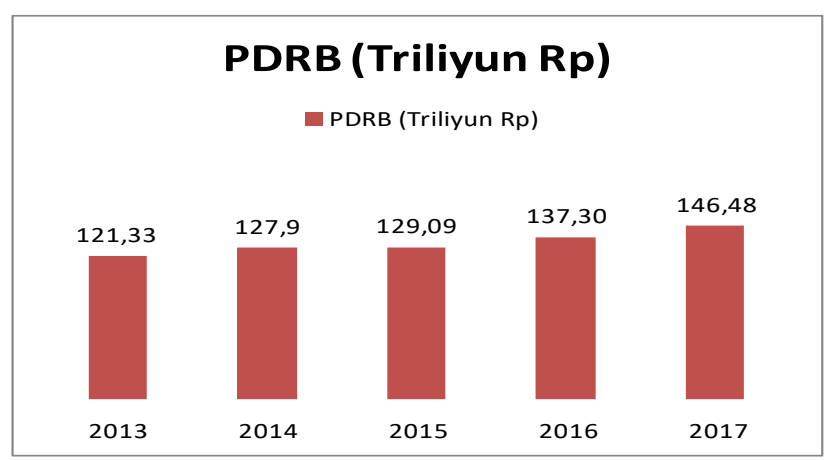

Sumber :https://aceh.bps.go.id

\section{Gambar 1}

Produk Domestik Regional Bruto (PDRB) Provinsi Aceh 2013-2017
Perkembangan nilai PDRB selama tahun 2013-2017 mengalami kenaikan dari tahun ke tahun. Pada tahun 2013, nilai PDRB sebesar121,33 triliun rupiah. Kemudian pada tahun 2014 naik menjadi 127,90 triliun rupiah. Nilai PDRB ini terus meningkat di tahun 2015 menjadi 129,09 triliun rupiah dan di tahun 2016 sebesar 137,30 triliun rupiah. Pada tahun 2017, nilai PDRB sudah mencapai 146,48 triliun rupiah. Kenaikan PDRB tertinggi terjadi di tahun 2017 yaitu sebesar 6,69 persen atau naik 9,18 triliun rupiah dari tahun 2016. Selama kurun waktu lima tahun Aceh telah mengalami kemajuan perekonomian dengan kenaikan PDRB sebesar 25,15 triliun rupiah.

Dengan tingkat pertumbuhan ekonomi yang tinggi, pemerintah Acehmempunyai kewajiban untuk memastikan bahwa PDRB tersebut dapatmencapai kemakmuran dan kesejahteraan bagi masyarakat.Kesejahteraan masyarakat dapat dicapai apabila kegiatan ekonomi terus meningkat melalui peningkatan PDRB.

Salah satu cara untuk memicu kegiatan ekonomi adalah melalui belanja pemerintah, dana perimbangan dan pendapatan asli daerah (PAD).Perkembangan belanja pemerintah, dana 
perimbangan dan PAD Provinsi Aceh dapat di gambarkan sebagai berikut :

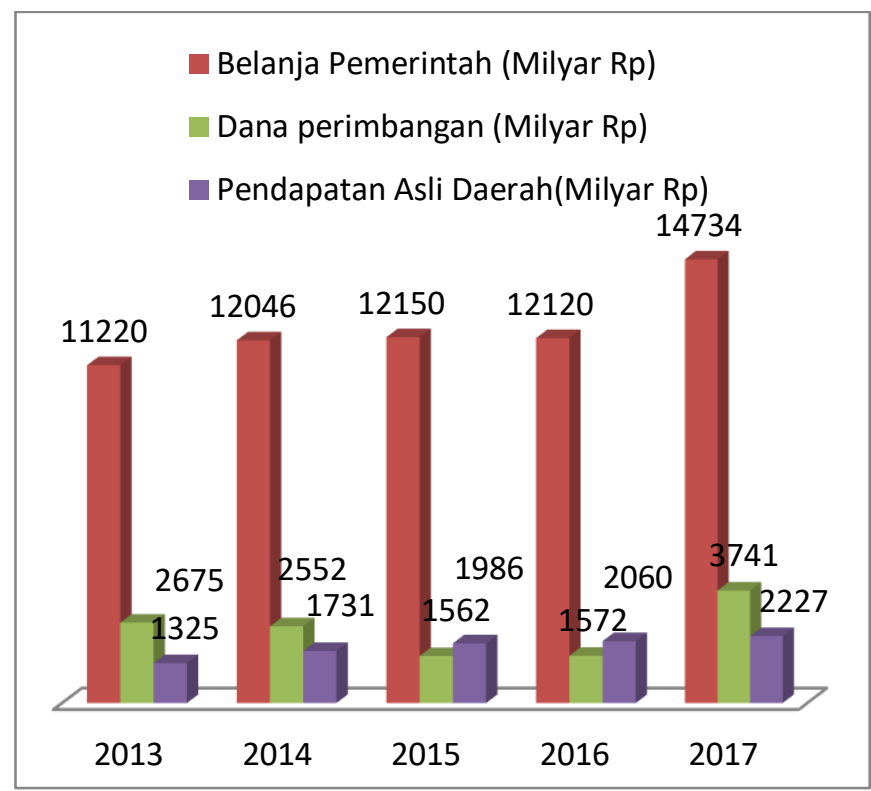

Sumber :https://aceh.bps.go.id

\section{Gambar 2}

\section{Belanja Pemerintah, Dana Perimbangan Dan Pendapatan Asli Daerah Provinsi Aceh 2013-2017}

Pada gambar di atas dapat dilihat bahwa belanja pemerintah Provinsi Aceh terus mengalami peningkatan dari tahun 2013 sampai dengan tahun 2015 mencapai 11220 hingga 12150 Milyar rupiah. Pada tahun 2016 belanja pemerintah turun menjadi 12120 milyar rupiah dari tahun sebelumnya, sementara dana perimbangan mengalami penurunan sebesara 990 milyar rupiah sehingga dana perimbangan hanya mencapai 1562 milyar rupiah dari tahun sebelumnya yaitu 2552 milyar rupiah. Namun ternyata penurunan dalam belanja pemerintah dan dana perimbangan tidak membuaut PDRB turun. Hal ini dapat dilihat pada gambar 1 PDRB terus mengalami peningkatan dari tahun 2013-2017.Hal ini tentu merupakan suatu hal yang menggembirakan. Namun jika dana perimbangan dan belanja pemerintah dapat terus ditingkatkan maka akan lebih mempertinggi PDRB.

Berdasarkan latar belakang di atas, maka penulis ingin mengetahui lebih lanjut mengapa pada tingkat belanja pemerintah dan dana perimbangan rendah justru PDRB meningkat. PDRB seolah-olah tidak terpengaruh oleh tinggi atau rendahnya belanja daerah dan dana perimbangan.

\section{TINJAUAN TEORITIS}

\section{Produk Domesik Regional Bruto (PDRB)}

Indikator yang sering dipakai untuk menilai kinerja perekonomian suatu negara adalah Produk Domestik Bruto (PDB), sedangkan indikator untuk melihat kinerja ekonomi suatu wilayah dalam suatu negara tertentu digunakan PDRB (Produk Domestik Regional Bruto), yang merupakan keseluruhan nilai tambah yang timbul akibat adanya berbagai aktivitas ekonomi yang dilakukan dalamsuatu wilayah terutama yang dikaitkan dengan kemampuan wilayah tersebut dalam mengelola sumber daya yang dimiliki.

Prioritas utama pemerintah daerah adalah mencapai pertumbuhan ekonomi yang tinggi dan menciptakan kesejahteraan bagi masyarakatnya.Pada masa era pelaksanaan otonomi daerah, kemajuan ekonomi daerah tidak lagi bergantung pada pemerintah pusat, sebab pemerintah daerah berwenang mengurus, mengelola, dan mengembangkan potensi daerah masing-masing.Pada tingkat daerah , pertumbuhan ekonomi terproksikan dalam bentuk variabel Produk Regional Domestik Bruto (PDRB). PDRB dapat diartikan sebagai neraca makro ekonomi yang dihitung secara konsisten dan terintegrasi berdasarkann konsep, definisi, klasifikasi dan cara penghitungan yang telah disepakati secara Internasional, (Statistik Keuangan Pemerintah Daerah Provinsi Aceh 2013-2017.).

\section{Belanja Pemerintah}

Pengeluaran pemerintah menurut Sukirno (1994)adalah merupakan bagian dari kebijakan fiskal, yang ditujukan untuk mengatur jalannya perekonomian dengan cara menentukan besarnya penerimaan dan pengeluaran pemerintah setiap tahunnya, yang tercermin dalam dokumen.

Anggaran Pendapatan Belanja Negara (APBN) untuk nasional dan Anggaran Pendapatan Belanja Daerah (APBD) untuk daerah atau regional. Tujuan dari kebijakan fiskal ini adalah dalam rangka menstabilkan harga, tingkat output, maupun kesempatan kerja dan memacu atau mendorong pertumbuhan ekonomi. 
Menurut Halim (2002) mengemukakan bahwa: "Belanja Daerah merupakan penurunan dalam manfaa ekonomi selama periode akuntansi dalam bentuk arus kas keluar atau deplesi asset, atau terjadinya utang yangmengakibatkan berkurangnya ekuitas dana, selain yang berkaitan dengan distribusi ke pada para peserta ekuitas dana".

Belanja daerah merupakan salah satu indikator yang menunjukkan pertumbuhan ekonomi jangka panjang dan kesejahteraan masyarakat. Semakin besar belanja daerah maka akan semakin memperbesar PDRB. (Mardiasmo, 2002).

\section{Dana Perimbangan}

Dana Perimbangan merupakan pendanaan daerah yang bersumber dari APBN yang terdiri dari Dana Bagi Hasil (DBH), Dana Alokasi Umum (DAU), dan Dana Alokasi Khusus (DAK). Dana Bagi Hasil bersumber dari pajak dan sumber daya alam yang dibagikan kepada daerah berdasarkan presentase tertentu.DAU bersumber dari pendapatan APBN yang dialokasikan dengan tujuan pemerataan kemampuan keuangan antar daerah untuk mendanai kebutuhan daerahh dalam rangka pelaksanaan Desentralisasi. DAK mmerupakan dana yang berasal dari APBN dan dialokasikan ke daerah yang dimaksudkan untuk membantu membiayai kegiatan khusus daerah dan sesuai dengan prioritas nasional. Davey dalam Waluyo $(2007,2)$ mengelompokkan DAU dan DBH sebagaiblock grants,sedangkan DAK merupakan specific grants. Penggunaan danablock grants diserahkan sepenuhnya kepada pemerintah daerah, sedangkan untukspecific grants penggunaannya ditentukan oleh pemerintah pusat dan pemerintah daerah wajib menyediakan dana pendamping sebesar $10 \%$ sebagaimana diatur dalam pasal 38-41 UU No 33 Tahun 2004.

Dari pernyataan yang disebutkan oleh waluyo maka dapat diambil kesimpulan bahwa semakin besar dana perimbangan yang di alokasikan maka akan semakin besar pula PDRB pada suatu wilayah tertentu.

\section{Pendapatan Asli Daerah (PAD)}

Pendapatan Asli Daerah (PAD) merupakan salah satu sumber penerimaan daerah yang juga merupakan modal dasar pemerintah daerah dalam mendapatkan dana pembangunan dan memenuhi belanja daerah. Indikator penting keberhasilan kemampuan keuangan daerah tercermin dalam kemampuan suatu daerah dalam menggali Pendapatan Asli daerah (PAD) nya untuk membiayai belanja rutin dan pembangunan di daerah tersebut.Keberhasilan desentralisasi fiskal jelas mensyaratkan keberhasilan daerah dalam mengelola potensi keuangan daerahnya. Menurut UU No. 25 Tahun 1999, sumber pendanaan pelaksanaan kegiatan pemerintah daerah terdiri atas Pendapatan Asli Daerah (PAD), Dana Perimbangan, dan Lain-lain Pendapatan yang sah. PAD merupakan bentukrevenue assignmentdalam konsep desentralisasi fiskal, dimana daerah diberi kewenangan untuk memanfaatkan serta mengelola sumber-sumber keuangannya sendiri untuk membiayai pelaksanaan fungsi dan tanggungjawab yang dilimpahkan oleh pemerintah pusat sebagai perwujudan desentralisasi. Menurut pasal $6 \mathrm{UU}$ No 33 tahun 2004, PAD terdiri atas : a) pajak daerah, b) retribusi daerah, c) hasil pengelolaan kekayaan daerah yang dipisahkan, dan d lain-lain PAD yang sah.

Dari pernyataan diatas maka dapat diambil kesimpulan bahwa semakin banyak Pendapatan Asli Daerah (PAD) maka akan semakin besar PDRB nya.

\section{Hipotesis}

Belanja Daerah (BD), Dana Perimbangan (DP) dan PAD berpengaruh positif dan signifikan terhadap PDRB

\section{METODE PENELITIAN}

Objek dari penelitian ini adalah belanja pemerintah, dana perimbangan, Pendapatan Asli Daerah dan PDRB dalam kurun waktu 2013.12017.4. Lokasi penelitian dilakukan di Propinsi Aceh.Penelitian ini dianalisa dengan menggunakan metode OLS (Ordinary Least Square) melalui analisis regresi linear berganda. 
$\log P D R B=a+b_{1} B D+b_{2} D P+b 3 P A D+e$

Dimana:

\begin{tabular}{|c|c|}
\hline PDRB & $\begin{array}{l}\text { Produk Domestik } \\
\text { (Triliyun Rupiah) }\end{array}$ \\
\hline $\mathrm{BD}$ & $\begin{array}{l}\text { Belanja Daerah } \\
\text { Rupiah) }\end{array}$ \\
\hline DP & $\begin{array}{l}\text { : Dana Perimbangan } \\
\text { Rupiah) }\end{array}$ \\
\hline PAD & $\begin{array}{c}\text { Pendapatan Asli } \\
\text { (Milyar Rupiah) }\end{array}$ \\
\hline
\end{tabular}

\section{HASIL PENELITIAN DAN PEMBAHASAN}

Dari penelitian yang dilakukan dalam kurun waktu 2013.1-2017.4, maka diperoleh hasil secara kuantitatif sebagai berikut :

\section{Tabel 1}

\section{Hasil Estimasi}

\begin{tabular}{ccccc} 
Variable & Coefficient & Std. Error & t-Statistic & Prob. \\
\hline \hline C & 0.128410 & 0.000462 & 278.1442 & 0.0000 \\
BD & $1.26 \mathrm{E}-06$ & $7.83 \mathrm{E}-08$ & 16.10990 & 0.0000 \\
DP & $-1.10 \mathrm{E}-06$ & $8.01 \mathrm{E}-08$ & -13.77291 & 0.0000 \\
PAD & $-5.06 \mathrm{E}-06$ & $2.76 \mathrm{E}-07$ & -18.30572 & 0.0000 \\
LOG(PDRB-1) & 0.971587 & 0.000136 & 7145.906 & 0.0000 \\
\hline \hline
\end{tabular}

\begin{tabular}{llll}
\hline R-squared & 1.000000 & & \\
Adjusted R-squared & 1.000000 & & \\
F-statistic & $2.01 \mathrm{E}+08$ & Durbin-Watson stat & 0.960029 \\
Prob(F-statistic) & 0.000000 & & \\
\hline
\end{tabular}

Sumber: Hasil penelitian ( Data diolah, eviews ver.10)

Dari tabel di atas dapat dilihat bahwa adjusted R-Square $100 \%$. Ini menunjukkan bahwa belanja daerah, dana perimbangan dan PAD dengan sempurna dapat menjelaskan pengaruhnya terhadap PDRB.

Secara parsial dan simultan belanja daerah, dana perimbangan dan PAD berpengaruh secara signifikan terhadap PDRB.

Dari hasil estimasi maka dalam penelitian ini dapat dijelaskan beberapa hal yaitu :

1. Variabel Belanja Daerah (BD) berpengaruh positif dan signifikan terhadap PDRB dengan koefesien 1.26E-06 yang berarti bila Belanja daerah ditingkatkan sebanyak 1 milyar rupiah maka PDRB akan meningkat sebanyak 1260 Triliyun Rupiah.

2. Variabel Dana Perimbangan (DP) berpengaruh negatif dan signifikan terhadap PDRB dengan koefesien -1.10E-06 yang berarti bila Dana Perimbangan meningkat sebanyak 1 milyar rupiah maka PDRB akan turun sebesar 1100 Triliyun Rupiah. Hal ini tidak sesuai dengan hipotesis. Ketidaksesuaiaan ini kemungkinan disebabkan karena pengelolaan APBD di berbagai daerah pada provinsi Aceh masih belum efektif. Hal ini ditunjukkan oleh alokasi belanja pegawai yang terus meningkat, sebaliknya porsi belanja modal untuk pembangunan justru menurun, sehingga PDRB mengalami penurunan.

3. Variabel PAD berpengaruh negatif dan signifikan terhadap PDRB dengan koefesien -5.06E-06 yang berarti setiap peningkatan PAD 1 milyar rupiah maka akan menurunkan PDRB 5060 Triliyun Rupiah. Hal ini tidak sesuai dengan hipotesis. Ketidaksesuaian ini disebabkan pengalokasian PAD terhadap belanja modal lebih kecil dibandingkan belanja tidak langsung sehingga PDRB mengalami penurunan.

\section{KESIMPULAN \\ Kesimpulan}

Belanja Daerah (BD) berpengaruh positif dan signifikan terhadap PDRB.Dana Perimbangan (DP) berpengaruh negatif dan signifikan terhadap PDRB. Hal ini disebabkan oleh pengelolaan APBD di berbagai daerah pada provinsi Aceh masih belum efektif.Hal ini ditunjukkan oleh peningkatan alokasi belanja pegawai, sementara belanja modal untuk pembangunan justru menurun, sehingga PDRB mengalami penurunan.

PAD berpengaruh negatif dan signifikan terhadap PDRB. Hal ini disebabkan oleh pengalokasian PAD terhadap belanja modal lebih kecil dibandingkan belanja tidak langsung sehingga PDRB mengalami penurunan. 
DAFTAR PUSTAKA

Halim, Abdul. (2002). Akuntansi Keuangan

Daerah. Jakarta: Salemba Empat

Mardiasmo.(2002). Akutansi Sektor public.

Penerbit: Andi

Statistik Keuangan Pemerintah Daerah

Provinsi Aceh 2013-2017

Sukirno, Sadono. (1994). Pengantar Teori Makro

Ekonomi, Jakarta: Raja Grafindo Persada.

Undang-Undang Nomor 25 Tahun 1999 tentang

Perimbangan dan Keuangan antara

Pemerintah Pusat dan Daerah.

Undang-Undang Nomor 33 Tahun 2004 tentang

Perimbangan dan Keuangan antara

Pemerintah Pusat dan Daerah.

Waluyo.(2007). Manajemen Publik. Konsep, Aplikasi\& Implementasinya Dalam

Pelaksanaan Otonomi Daerah.Bandung:

Mandar Maju. 